\title{
Study on Heritability, Correlation and Genetic Divergence in Okra (Abelmoschus esculentus)
}

\author{
Priya Priyanka Tudu*, Vijay Bahadur, Anita Kerketta and Suraj Luthra
}

Department of Horticulture, Naini Agricultural Institute, Sam Higginbottom University of Agriculture, Technology and Sciences, Prayagraj-211007, U.P., India

*Corresponding author

\section{Keywords}

Abelmoschus esculentus, Malvaceae family, chromosome, curry and soup

\section{Article Info}

Accepted: 12 May 2021 Available Online: 10 June 2021
The Genotypes Annu 50 (240.g) and $10.45 \mathrm{t} \mathrm{ha}^{-1}$ ) was recorded highest mean performance for fruit yield plant-1 and no. of fruit plant-1). The genotypic coefficient variance value were categorized as low (0-10\%), moderate (10-20\%) and high (20\% and above). In the present study the heritability estimates in broad sense were classified into 3 groups such as high $(>75 \%)$, moderate $(60 \%-75 \%)$, low $(<60 \%)$. The genetic advance estimates were found to be high for Plant height, and Yield plant ${ }^{-1}(\mathrm{~g})$. The high genetic advance as percent of mean was recorded for Plant height, Number of branches per plant, Fruiting node, Fruit length $(\mathrm{cm})$, Fruit width $(\mathrm{cm})$ and Fruit weight $(\mathrm{g})$. Genotypic and phenotypic coefficient analysis revealed that fruit yield per plant showed positive significant association with Plant height, Length of internodes $(\mathrm{cm})$, Days taken to first picking, Number of nodes to first flowering and Fruit yield $\left(\mathrm{t} \mathrm{ha}^{-1}\right)$. Genotypic and phenotypic that highest direct positive effect on fruit yield per plant (g) was exhibited by Number of branches per plant, Length of internodes $(\mathrm{cm})$ at both genotypic and phenotypic and Days taken to $50 \%$ flowering, Number of fruit per plant, Days taken to first picking, Number of nodes to first flowering and Fruiting node at phenotypic and Fruit length $(\mathrm{cm})$, Fruit weight $(\mathrm{g})$, Fruit yield $\left(\mathrm{t} \mathrm{ha}^{-1}\right)$ at both genotypic and phenotypic level. Clustering pattern indicated that cluster $\mathrm{I}$ is largest cluster comprising 18 out of twenty-two genotype. On the other hand cluster II, comprised 1 genotype, cluster III, IV, V cluster comprised 1 genotype. The inter cluster distance was maximum between cluster IV and V (435.065) Cluster I, II, III, IV, V was characterized by high mean value for plant height $(\mathrm{cm})$ and low mean values for Fruit width $(\mathrm{cm})$. The highest contribution in manifestation of genetic divergence was exhibited by Number of fruits per plant,. Days taken to first flowering, Fruiting node, Fruit length $(\mathrm{cm})$, Fruit width $(\mathrm{cm})$, Fruit weight (g) and Yield per plant $(\mathrm{g})$ and Yield per plants $\left(\mathrm{t} \mathrm{ha}^{-1}\right)$. 


\section{Introduction}

Okra is one of the important members of Malvaceae family having higher chromosome number of $2 n=130$ and polyploidy in nature. The family Malvaceae consists of about 34 Abelmoschus species, including 30 species in the Old World and four in the New World (Joshi et al., 1974). Okra (Abelmoschus esculentus) is one of the important tropical vegetables commonly known as Okra in India. It is the most ancient and traditional vegetable crop grown in tropical and sub-tropical low land regions of Asia, Africa, America and warmer parts of Mediterranean regions.

Tender green fruits are cooked in curry and soup, while crop has not adapted in India as leafy vegetable as in for East countries. The cultivated species A. esculentus is believed to be originated in the Hindustani centre, i.e., India according to the taxonomic classification of Zeven and Zhukovsky(1975).

According to Vavilov, it was probably domesticated in the Ethopian region but according to Murdock it is in West Africa. Okra is known by many local names in different parts of the world. It is called lady's finger in England, Gumbo in U.S.A. and Bhindi in India. Edible fresh and tender fruits contain $88 \%$ moisture and large number of chemical components including Vit. A 88 IU, B $63 \mathrm{IU}$ and C $13 \mathrm{mg} / 100 \mathrm{gm}$. Immature okra fruits contain 3100 calorie energy, $1.8 \mathrm{~g}$ protein, $90 \mathrm{mg}$ calcium and $1.0 \mathrm{mg}$ iron (Aykroyd, 1941).The species A. tuberculatus, a wild type is native to India. The Seeds of okra (Pusamakhmali) had the highest oil content $17.3 \%$ which is a nutritious ingredient of cattle feed. It has Ayurvedic medicinal properties. Its leaves are used for preparing a medicament to reduce inflammation. It is an excellent source of Iodine for control of goiter (Chadha, 2001). In India It is grown twice in a year for getting regular supply. In the country, a large number of okra varieties are grown, the variation occurs with regards to quantitative and qualitative traits. The plant height, number of primary branches per plant, number of fruits per plant, size of fruit i.e. length as well as weight of fruits are the yield contributing characters while, colour of fruit and fiber content determine the quality of fruit.

\section{Materials and Methods}

The present investigation was carried out at the horticulture Research Farm, Department of Horticulture, Naini Agricultural Institute, Sam Higginbottom University of Agriculture, Science and Technology, Prayagraj. The experimental material comprised of twenty two genotypes including check, which were collected from different source (Table 1). The genotypes were grown in a randomized block design with three replicates during monsoon season keep line to line distance of $30 \mathrm{~cm}$. and plant to plant distance of $30 \mathrm{~cm}$ during the year 2019-2020. Five competitive plants were selected at randomly tagged from each plot to record observation on various characters viz., plant height, number of branches per plants, Fruiting node, fruit length $(\mathrm{cm})$, fruit width $(\mathrm{cm})$, Fruit weight $(\mathrm{g})$, days to 50 per cent flowering, Fruit yield $\left(\mathrm{tha}^{-1}\right)$

Coefficient Of Variation (Burton, 1952). Genetic Advance (Lush, 1949). On the basis of percent of mean were worked out according to the method advocated by Correlation Coefficient Analysis (Al-Jibour et al, 1958), respectively.

\section{Results and Discussion}

The mean sum of squares due to 22 genotypes showed significant differences for all characters at $1 \%$ level and 5\% level of significance, indicating the presence of substantial amount of genetic variability among the okra genotypes. The highest fruit 
yield per plant $(\mathrm{g})$ was recorded in Annu 50 (240.00) (gm). However, it was found the lowest in Red ruby and okra 107(155.00).

The heritability estimates were found to be high (more than 60\%) for Plant height (96), Number of branches per plant (80), Length of internodes $(\mathrm{cm})(68)$, Number of nodes to firs flowering (64), Days taken to first flowering (63), Days taken to first picking (62), Fruiting span (83), Fruit length (cm) (61), Fruit width (cm) (78), Fruit weight (g) (91), Number of fruit per plant (88). The genetic advance estimates were found to be high for Plant height (36.89) and Yield per plant (g) (36.67) and genetic advance as percent of mean was recorded for Plant height (48.02), Number of branches per plant (30.10), Fruiting span (25.88), Fruit length $(\mathrm{cm})$ (32.68), Fruit width (cm) (35.53) and Fruit weight (g)(55.24).Genotypic correlation coefficient analysis revealed that fruit yield per plant showed positive significant association with Plant height $\left(0.214^{* *}\right)$, Length of internodes (cm) $(0.3840 *)$, Days taken to first picking $\left(0.4608^{* *}\right)$, Number of nodes to first flowering $\left(0.4404^{* *}\right)$ and Fruit yield $\left(\mathrm{t} \mathrm{ha}^{-1}\right)$ $(1.0008 *$. While as negative significant association was observed with Days taken to $50 \%$ flowering $\left(-0.3683^{*}\right)$, Days taken to first picking $\left(-0.4608^{* *}\right)$, Fruit width $(\mathrm{cm}) \quad(-$ $\left.0.3239^{*}\right)$.

Table.1 List of Genotype

\begin{tabular}{|c|c|c|}
\hline SL No. & $\begin{array}{c}\text { Genotypes } \\
\text { Symbol }\end{array}$ & Name of Genotypes \\
\hline $\mathbf{1}$ & $\mathrm{G}_{1}$ & ArkaAnamika \\
\hline $\mathbf{2}$ & $\mathrm{G}_{2}$ & Sahiba \\
\hline $\mathbf{3}$ & $\mathrm{G}_{3}$ & Red Rubby \\
\hline $\mathbf{4}$ & $\mathrm{G}_{4}$ & Super Green \\
\hline $\mathbf{5}$ & $\mathrm{G}_{5}$ & Samrat \\
\hline $\mathbf{6}$ & $\mathrm{G}_{6}$ & Okra 1182 \\
\hline $\mathbf{7}$ & $\mathrm{G}_{7}$ & SB-6X747 \\
\hline $\mathbf{8}$ & $\mathrm{G}_{8}$ & Annu 50 \\
\hline $\mathbf{9}$ & $\mathrm{G}_{9}$ & Champion \\
\hline $\mathbf{1 0}$ & $\mathrm{G}_{10}$ & SB-8XVRO-102 \\
\hline $\mathbf{1 1}$ & $\mathrm{G}_{11}$ & IC-43735 \\
\hline $\mathbf{1 2}$ & $\mathrm{G}_{12}$ & Bhindi PG-15 \\
\hline $\mathbf{1 3}$ & $\mathrm{G}_{13}$ & IC-218872 \\
\hline $\mathbf{1 4}$ & $\mathrm{G}_{14}$ & SB-6X746 \\
\hline $\mathbf{1 5}$ & $\mathrm{G}_{15}$ & Okra 326-10-1 \\
\hline $\mathbf{1 6}$ & $\mathrm{G}_{16}$ & SB-8XOKHYB-4 \\
\hline $\mathbf{1 7}$ & $\mathrm{G}_{17}$ & Okra 231-10-1 \\
\hline $\mathbf{1 8}$ & $\mathrm{G}_{1}$ & Okra 304-10-1 \\
\hline $\mathbf{1 9}$ & $\mathrm{G}_{19}$ & VROSXVRO-101 \\
\hline $\mathbf{2 0}$ & $\mathrm{G}_{20}$ & VRO 107 \\
\hline $\mathbf{2 1}$ & $\mathrm{G}_{21}$ & OKRA 107 \\
\hline $\mathbf{2 2}$ & $\mathrm{G}_{22}$ & Okra 232-10-1 \\
\hline
\end{tabular}


Table.2 Analysis of Variance for various characters in okra genotypes

\begin{tabular}{|c|c|c|c|c|}
\hline $\begin{array}{l}\text { S. } \\
\text { No. }\end{array}$ & Characters & $\begin{array}{c}\text { Replication } \\
=\text { df } 2\end{array}$ & Treatment $=\mathbf{d f 1 7}$ & $\begin{array}{l}\text { Error } \\
=\text { df34 }\end{array}$ \\
\hline 1. & Plant height & 74.83 & $1010.92 * *$ & 12.44 \\
\hline 2. & Number of leaves per plant & 9.06 & $15.003 * *$ & 5.98 \\
\hline 3. & Number of branches per plant & 0.1810 & $1.103 * *$ & 0.083 \\
\hline 4. & Length of internodes $(\mathrm{cm})$ & 0.646 & $2.460 * *$ & $\mathbf{0 . 3 2 3}$ \\
\hline 5. & Number of nodes to first flowering & 0.353 & $0.739 * *$ & 0.112 \\
\hline 6. & Days taken to first flowering & 2.86 & $17.77 * *$ & 2.86 \\
\hline 7. & Days taken to $50 \%$ flowering & 1.05 & $17.81 * *$ & 3.45 \\
\hline 8. & Days taken to first picking & 0.689 & $21.37 * *$ & 3.52 \\
\hline 9. & Fruiting node & 2.039 & $1.98 * *$ & 0.121 \\
\hline 10. & Fruit length $(\mathrm{cm})$ & 1.95 & $17.86 * *$ & 3.08 \\
\hline 11. & Fruit width $(\mathrm{cm})$ & 0.0126 & $0.180 * *$ & 0.0154 \\
\hline 12. & Fruit weight $(\mathrm{g})$ & 1.44 & $23.99 * *$ & 0.74 \\
\hline 13. & Number of fruit per plant & 0.451 & $11.69 * *$ & 0.500 \\
\hline 14. & Yield per plant (g) & 91.676 & $1073.33 * *$ & 32.73 \\
\hline 15. & Fruit yield (t ha $\left.{ }^{-1}\right)$ & 0.186 & $1.714 * *$ & 0.0615 \\
\hline
\end{tabular}

$*$ and $* *$ significant at $5 \%$ and $1 \%$ level of significance respectively 
Table.3 Estimates of Path Analysis coefficient for 15 growth and yield component with fruit yield per plant

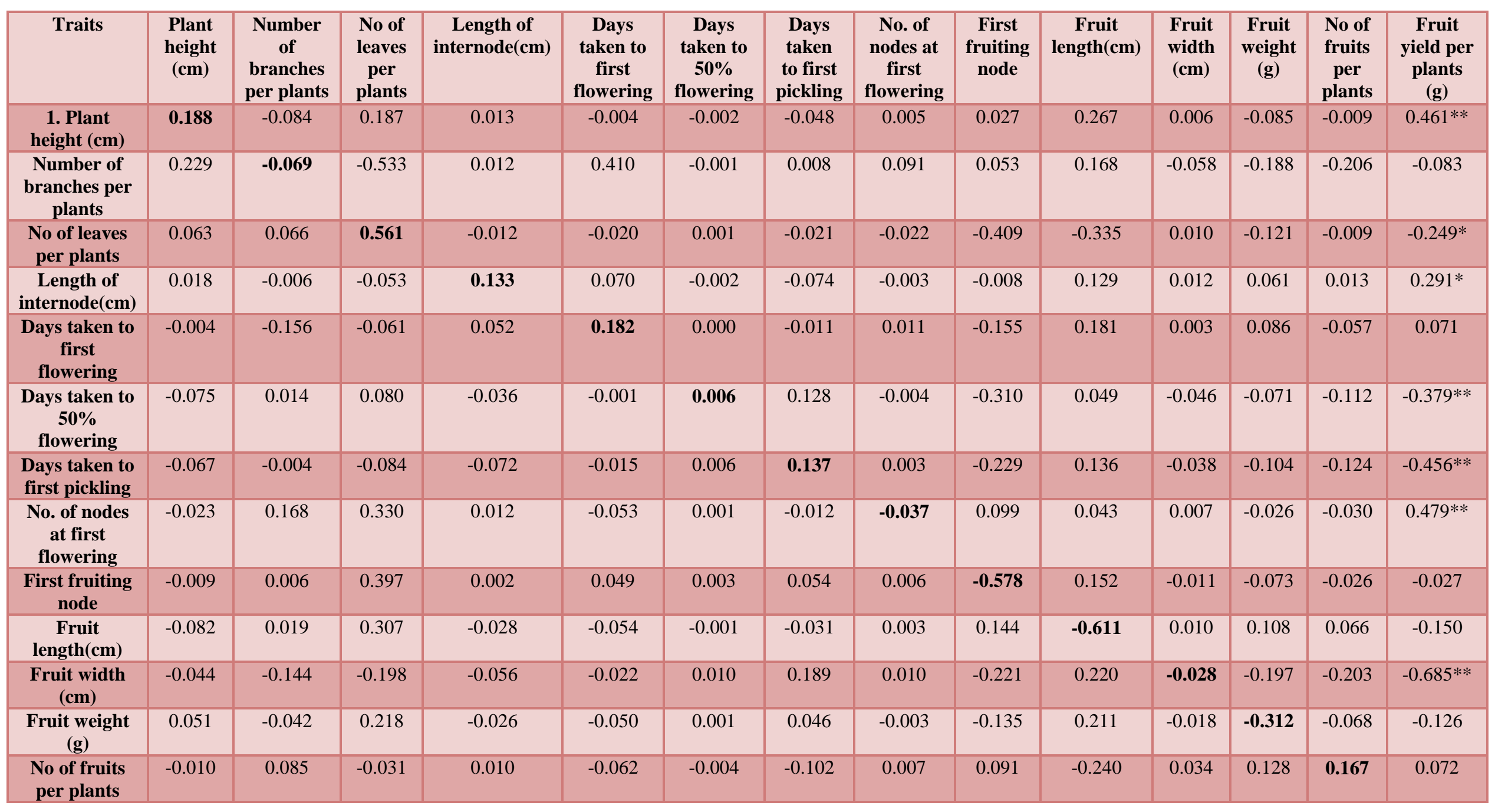


Table.4 Estimates of genotypic correlation coefficient for 15 growth and yield component with fruit yield per plant

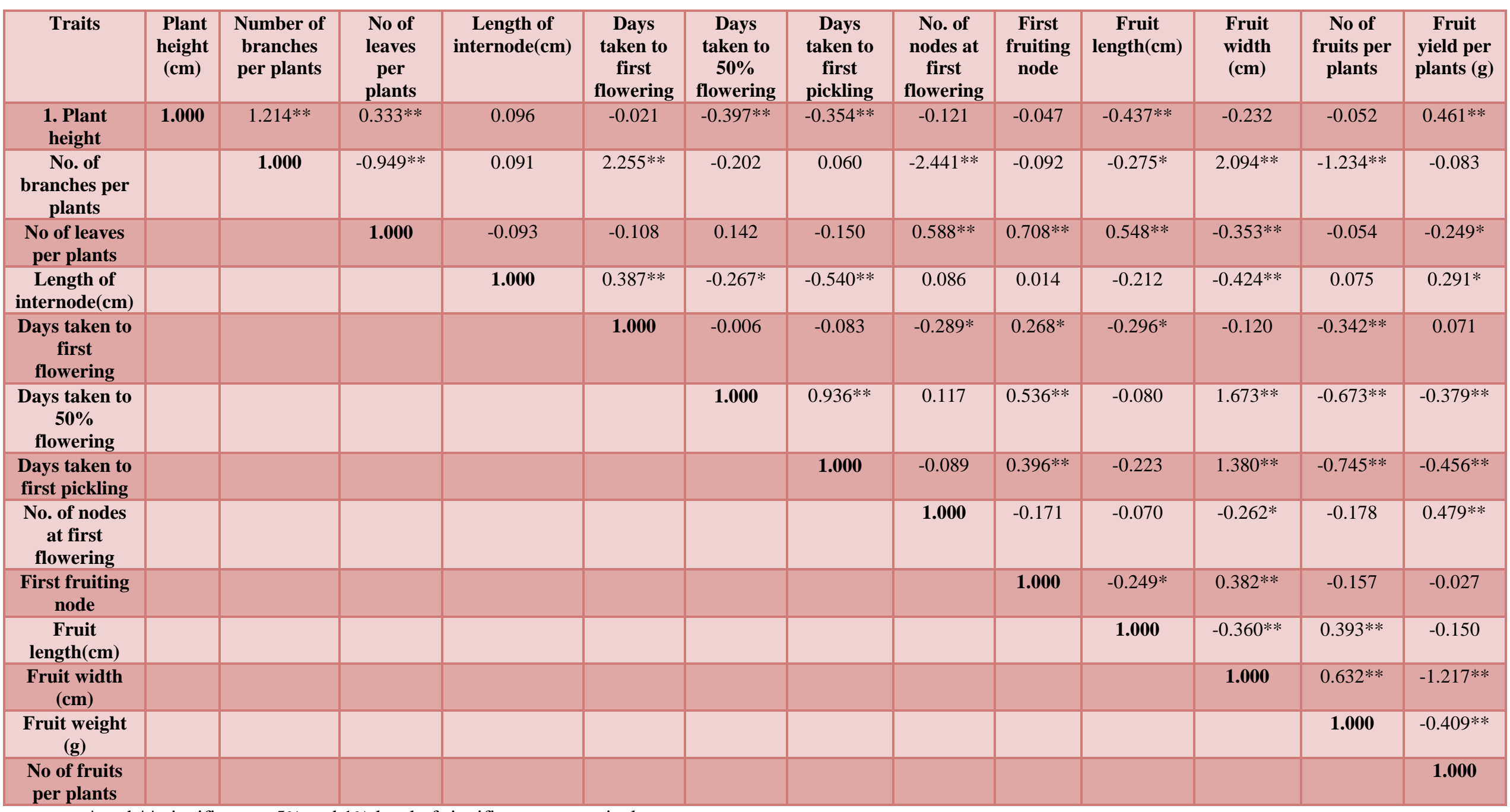

$*$ and $* *$ significant at $5 \%$ and $1 \%$ level of significance respectively 
Table.5 Clustering pattern of 22 Okra (Abelmoschus esculentus L.) genotypes based on $\mathrm{D}^{2}$ statistics.

\begin{tabular}{|c|c|c|}
\hline Clusters & $\begin{array}{c}\text { No. of } \\
\text { Genotypes }\end{array}$ & $\begin{array}{c}\text { Name of the Genotypes } \\
\text { Cluster-I }\end{array}$ \\
& 18 & $\begin{array}{c}\text { SB-1X1101, IC-42735, OKRA 304-10-1, ArkaAnamika, } \\
\text { Super Green, Sahiba, Okra 107, Samrat, 326-10-1, SB- } \\
\text { 8XVRO-102, Champion, Bhindi PG-15, VRO5XVRO-101, } \\
\text { SB-8XOKHYB-4, IC-218872,231-10-1 \& SB-6X747 }\end{array}$ \\
\hline Cluster-II & 1 & $\mathbf{2 3 2 - 1 0 - 1 ,}$ \\
\hline Cluster-III & 1 & SB-6 X 746 \\
\hline Cluster-IV & 1 & Red ruby \\
\hline Cluster - V & 1 & Annu 50 \\
\hline
\end{tabular}

Table.6 Intra and inter cluster distance ( $\mathrm{D}^{2}$ ) of Okra (Abelmoschus esculentus L.) genotypes

Euclidean² $^{2}$ Cluster Distances : Ward

\begin{tabular}{|l|c|c|c|c|c|}
\hline & 1 Cluster & 2 Cluster & 3 Cluster & 4 Cluster & 5 Cluster \\
\hline $\mathbf{1}$ Cluster & 48.254 & 76.944 & 190.723 & 89.006 & $\mathbf{1 5 1 . 1 1 6}$ \\
\hline 2 Cluster & & 67.907 & 187.745 & 93.042 & $\mathbf{1 7 2 . 1 8 0}$ \\
\hline 3 Cluster & & & 0.000 & 201.137 & $\mathbf{4 3 5 . 0 6 5}$ \\
\hline $\mathbf{4}$ Cluster & & & & 37.800 & $\mathbf{1 3 8 . 1 7 3}$ \\
\hline $\mathbf{5}$ Cluster & & & & & $\mathbf{0 . 0 0 0}$ \\
\hline
\end{tabular}

Cluster Distance

\begin{tabular}{|l|c|c|c|c|c|c|}
\hline \multicolumn{2}{|c|}{} & Cluster 1 & Cluster 2 & Cluster 3 & Cluster 4 & Cluster 5 \\
\hline Cluster & $\mathbf{1}$ & $\mathbf{2 0 . 5 3}$ & $\mathbf{3 1 . 7 1}$ & $\mathbf{3 5 . 7 9}$ & $\mathbf{5 0 . 5 4}$ & $\mathbf{6 3 . 0 3}$ \\
\hline Cluster & 2 & $\mathbf{3 1 . 7 1}$ & $\mathbf{0 . 0 0}$ & $\mathbf{6 8 . 5 0}$ & 44.65 & $\mathbf{7 7 . 7 2}$ \\
\hline Cluster & $\mathbf{3}$ & $\mathbf{3 5 . 7 9}$ & $\mathbf{6 8 . 5 0}$ & $\mathbf{0 . 0 0}$ & $\mathbf{6 3 . 8 8}$ & $\mathbf{6 9 . 2 2}$ \\
\hline Cluster & $\mathbf{4}$ & $\mathbf{5 0 . 5 4}$ & 44.65 & $\mathbf{6 3 . 8 8}$ & $\mathbf{0 . 0 0}$ & $\mathbf{1 4 5 . 0 2}$ \\
\hline Cluster & $\mathbf{5}$ & $\mathbf{6 3 . 0 3}$ & $\mathbf{7 7 . 7 2}$ & $\mathbf{6 9 . 2 2}$ & $\mathbf{1 4 5 . 0 2}$ & $\mathbf{0 . 0 0}$ \\
\hline
\end{tabular}

Cluster Means

\begin{tabular}{|c|c|c|c|c|c|c|c|c|}
\hline & & Char. 1 & Char. 2 & Char. 3 & Char. 4 & Char. 5 & Char. 6 & Char. 7 \\
\hline Cluster & 1 & 77.54 & 3.74 & 31.57 & 7.72 & 35.04 & 39.33 & 41.00 \\
\hline Cluster & 2 & 96.67 & 3.67 & 30.00 & 9.33 & 35.00 & 39.67 & 40.67 \\
\hline Cluster & 3 & 63.67 & 3.00 & 31.67 & 8.67 & 36.33 & 41.00 & 42.00 \\
\hline Cluster & 4 & 61.67 & 3.33 & 33.67 & 5.67 & 32.33 & 46.33 & 48.33 \\
\hline \multirow{2}{*}{ Cluster } & 5 & 119.33 & 3.33 & 32.67 & 8.67 & 33.00 & 36.00 & 36.00 \\
\hline & & Char. 8 & Char. 9 & Char. 10 & Char. 11 & Char. 12 & Char. 13 & Char. 14 \\
\hline Cluster & 1 & 4.91 & 5.57 & 11.67 & 1.17 & 9.52 & 10.93 & 175.56 \\
\hline Cluster & 2 & 4.67 & 6.33 & 7.67 & 1.33 & 15.33 & 8.67 & 170.00 \\
\hline Cluster & 3 & 6.00 & 4.67 & 10.33 & 1.33 & 7.00 & 6.67 & 185.00 \\
\hline Cluster & 4 & 5.67 & 7.33 & 9.33 & 1.67 & 15.33 & 8.33 & 155.00 \\
\hline Cluster & 5 & 6.00 & 5.67 & 9.33 & 1.00 & 10.67 & 13.00 & 240.00 \\
\hline
\end{tabular}


Table.7 Cluster mean values for twenty-two growth and yield characters of Okra (Abelmoschus esculentus L.)

\begin{tabular}{|c|c|c|c|c|c|c|}
\hline S. No. & Characters & Cluster 1 & Cluster 2 & Cluster 3 & Cluster 4 & Cluster 5 \\
\hline 1. & Plant height & 119.333 & 91.714 & 61.667 & 74.800 & 55.333 \\
\hline 2. & $\begin{array}{c}\text { Number of leaves per } \\
\text { plant }\end{array}$ & 3.333 & 3.905 & 3.333 & 3.667 & 3.333 \\
\hline 3. & $\begin{array}{l}\text { Number of branches } \\
\text { per plant }\end{array}$ & 32.667 & 32.048 & 33.667 & 30.800 & 32.556 \\
\hline 4. & $\begin{array}{l}\text { Length of internodes } \\
(\mathrm{cm})\end{array}$ & 8.667 & 8.000 & 5.667 & 7.800 & 7.667 \\
\hline 5. & $\begin{array}{l}\text { Number of nodes to } \\
\text { first flowering }\end{array}$ & 33.000 & 36.524 & 32.333 & 34.633 & 33.333 \\
\hline 6. & $\begin{array}{l}\text { Days taken to first } \\
\text { flowering }\end{array}$ & 36.000 & 39.333 & 46.333 & 39.733 & 38.667 \\
\hline 7. & $\begin{array}{l}\text { Days taken to } 50 \% \\
\text { flowering }\end{array}$ & 36.000 & 41.048 & 48.333 & 41.433 & 39.667 \\
\hline 8. & $\begin{array}{l}\text { Days taken to first } \\
\text { picking }\end{array}$ & 6.000 & 4.762 & 5.667 & 5.067 & 5.000 \\
\hline 9. & Fruiting node & 5.667 & 5.952 & 7.333 & 5.300 & 5.556 \\
\hline 10. & Fruit length $(\mathrm{cm})$ & 9.333 & 10.000 & 9.333 & 11.333 & 14.889 \\
\hline 11. & Fruit width $(\mathrm{cm})$ & 1.000 & 1.190 & 1.667 & 1.200 & 1.111 \\
\hline 12. & Fruit weight (g) & 10.667 & 10.952 & 15.333 & 9.167 & 8.444 \\
\hline 13. & $\begin{array}{l}\text { Number of fruit per } \\
\text { plant }\end{array}$ & 13.000 & 9.905 & 8.333 & 10.400 & 12.889 \\
\hline 14. & $\begin{array}{l}\text { Fruit yield plants } \\
\text { (g) }\end{array}$ & 240.000 & 176.667 & 155.000 & 177.500 & 167.778 \\
\hline
\end{tabular}

Table.8 Percent contribution of each character toward genetic divergence of Okra (Abelmoschus esculentus L.)

\begin{tabular}{|c|c|c|}
\hline Source & Times ranked 1st & Contribution \% \\
\hline 1 Plant height (cm) & 24 & $10.39 \%$ \\
\hline 2Numberofbranchesperplants & &.$\%$ \\
\hline 3 No of leaves per plants & 1 & $.43 \%$ \\
\hline 4 Length of internode(cm) & 1 & $.43 \%$ \\
\hline 5 Days taken to first flowering & 6 & $2.6 \%$ \\
\hline 6Daystakento50\%flowering & 32 & $13.85 \%$ \\
\hline 7 Days taken to first pickling & 2 & $.87 \%$ \\
\hline 8No.0fnodesatfirstflowering & &.$\%$ \\
\hline 9 First fruiting node & 28 & $12.12 \%$ \\
\hline 10 Fruit length(cm) & 7 & $3.03 \%$ \\
\hline 11 Fruit width (cm) & 5 & $2.16 \%$ \\
\hline 12 Fruit weight (g) & 56 & $24.24 \%$ \\
\hline 13 No of fruits per plants & 25 & $10.82 \%$ \\
\hline 14 Fruit yield per plants (g) & 44 & $19.05 \%$ \\
\hline
\end{tabular}


Phenotypic correlation coefficient analysis revealed that fruit yield per plant $(\mathrm{g})$ showed positive and significant association with Plant height $\left(0.4319^{* *}\right)$, Length of internodes $(\mathrm{cm})$ $\left(0.3157^{*}\right)$ and Number of nodes to first flowering $\left(0.3284^{*}\right)$ and Fruit yield $\left(\mathrm{t} \mathrm{ha}^{-1}\right)$ $(0.9970 * *)$. While as negative significant association was observed with Days taken to first picking $\left(-0.3443^{*}\right)$, Fruiting span ($\left.0.848^{* *}\right)$ Genotypic path coefficient revealed that highest direct positive effect on fruit yield per plant (g) was exhibited by Number of branches per plant (0.0435), Length of internodes (cm) (0.0357), Days taken to $50 \%$ flowering (0.0666), Fruit length (cm) (0.0040), Fruit weight (g) (0.0132), Number of fruit per plant (0.0145)Phenotypic path coefficient revealed that highest direct positive effect on fruit yield per plant (g) was exhibited by Number of branches per plant (0.0069), Length of internodes $(\mathrm{cm})(0.0074)$, Days taken to first picking (0.0120), Number of nodes to first flowering (0.0060), Fruiting span (0.0041), Fruit length (cm) (0.0095), Fruit weight (g) (0.0005).Clustering pattern indicated that cluster $\mathrm{I}$ is largest cluster comprising 18 out of twenty-two. On the other hand cluster II, cluster III, IV, V cluster comprised 1. The inter cluster distance was maximum between cluster IV and V (138.173) followed by cluster I and Cluster V (151.116), Cluster III and cluster V (435.065), cluster III and IV (201.137), Cluster II and IV(93.042). The Okra genotypes under investigation showed significant genetic variability. Based on mean performance for fruit yield per plant (300.00) and, genotypes Annu 50 were considered suitable genotypes in Prayagraj climatic condition..

\section{References}

Ade Oluwa, O. O. and Kehinde, O. B (2011). Genetic variability studies in West African okra (Abelmoschus caillei). Agriculture Biology Journal North
America, 2011, 2(10): 1326-1335.

Ahamed. K. U., Akter B., Ara N., Hossain M. F. and Moniruzzaman $\mathrm{M}$. (2015).Heritability, Correlation And Path Coefficient Analysis In Fifty Seven Okra Genotypes. International Journal Applied Science Biotechnology, 3(1):127-133.

Al-Jibouri, A., Miller, P. A. and Robison, H.F. (1958).Genotypic and environmental variation and co variation in upland cotton crops of interspecific origin. Agronomy. Journal, 50: 626-636.

Bagwale S. B., Jawale L. N, Deosarkar., D. B. and Jadhav., R. A. (2016).Genetic variability studies for yield, yield contributing and quality traits in okra [Abelmoschus esculentus (L.) Moench.]. Indian Journal of Agricultural Research, (50):614-618.

Burton and Devane (1953). Estimating heritability in tall Fesscue from replicated clonal marterial. Agronomy. Journal, 45: 474-481

Burton, G. W. (1955).Quantitative inheritance in grass. Proc. $6^{\text {th }}$ Int. Grassland Cong., 1: 227-283.

Cox T S, Murphy J P. (1990). Effect of parental divergence of $\mathrm{F} 2$ heterosis in winter wheat crosses. Theology Applied Genetics1990; 79:241-250.

Davinder Singh, Dudi B. S., Dhankhar S. K. and Rajkumar (2018). Genetic Diversity Analysis of Okra Genotypes Using Morphological Markers Internatinal Journal Current Microbiology Applied Science (2018) 7(1): 1667-1675.

Deepanshu and Abdul Shamad (2017).Genetic variability, heritability and correlation coefficient in okra (Abelmoschus esculentus (L.) moench) in Allahabad agroclimatic conditions. Plant Archives 17 No. 2, 2017 1597-1602.

Dewey, D. R. and Lu, K. H. (1959).A correlation and path analysis of the 
components of crested wheat grass seed production. Agronomy Journal, 51:515-518.

Dwivedi Meenakshee and Sharma D.P. (2017). Correlation and path analysis studies in okra [Abelmoschus esculentus L. Moench] under Jabalpur condition. 9, 34, 4504-4509.

Effing, G. S., Ogban, P. I., Ibia, T. O. and Adam, A. A., (2009).Evaluation of Nitrogen supplying Potentials of Fluted Pumpkin (Telfairiaoccidentalis, Hook, F.)And Okra (Abelmoschus esculentus) (L) Monech.Academic Journal of Plant Science. 2(3):209214.

Fisher, R. A. and Yates, A. H. (1938).Statistical tables for biological, agricultural and medical research. Olivar and Boyed. Edinburgh, 134-135

GovindShuirkar, A K Naidu, B R Pandey, A $\mathrm{K}$ Mehta, S K Dwivedi and $\mathrm{H} \mathrm{L}$ Sharma (2018). Correlation coefficient analysis in okra. The Pharma Innovation Journal 2018; 7(6): 644647
Guddadamath, S., Mohankumar, H. D., Salimath, P. M. and Sujatha, K., (2011).Genetic analysis of biparental mating and selfing in segregating populations of okra. Indian Journal Horticulture 68(3): 340-344.

Jeetendra Chavan, N Seenivasan, P Saidaiah and N Sivaraj (2019). Estimation of correlation coefficient and path coefficient analysis for yield and yield components in okra [Abelmoschus esculentus (L.) Moench]. International Journal of Chemical Studies 2019; 7(4): 1254-1260

Johnson, H. W., Robinson, H. F. and Comstock, R. E. (1955). Genotypic and phenotypic correlations in soybean and their implication in selection. Agronomy Journal,47: 477- 483.

Kandasamy, R. (2015). Genetic divergence in okra [Abelmoschus esculentus L. (Moench)].International Journal agriculture Science, 11 (1): 158- 160.

Khanna K R, Misra C H. (1977).Divergence and heterosis in tomato. SABRAO J.; 9:43- 50 .

\section{How to cite this article:}

Priya Priyanka Tudu, Vijay Bahadur, Anita Kerketta and Suraj Luthra. 2021. Study on Heritability, Correlation and Genetic Divergence in Okra (Abelmoschus esculentus). Int.J.Curr.Microbiol.App.Sci. 10(06): 356-365. doi: https://doi.org/10.20546/ijcmas.2021.1006.038 